UDC 612.821

DOI: 10.31651/2076-5835-2018-1-2021-2-71-79

Frolova Liudmyla Serhiivna

Assistant Professor, Ph. D., Department of sports games, The Bohdan Khmelnytsky National

University of Cherkasy, Ukraine

1-f2014@vu.cdu.edu.ua

ORCID: https://orcid.org/0000-0003-0763-7509

Chernenko Nataliia Pavlivna,

Assistant Professor, Ph. D., Department of Anatomy, Physiology and Physical Rehabilitation, The Bohdan Khmelnytsky National University of Cherkasy, Ukraine nataliya-chernenko2005@ukr.net

ORCID: https://orcid.org/0000-0002-8177-263X

Petrenko Yuriy Oleksiyovych

Assistant Professor, Ph. D., Department of Anatomy, Physiology and Physical Rehabilitation, The Bohdan Khmelnytsky National University of Cherkasy, Ukraine

Petrenko62@gmail.com

ORCID: https://orcid.org/0000-0002-6348-2110

\title{
FEATURES OF THE VISUAL-MOTOR REACTION OF YOUNG VOLLEYBALL PLAYERS AND ITS IMPACT ON THE ACCURACY OF THE ATTACKING BLOW
}

Introduction.The high speed and accuracy of the visual-motor reaction are the basis for the formation of the precision of volleyball players' movements. However, the visual-motor reaction of young volleyball players and its effect on the accuracy of an attack strike has not been studied.

Purpose.Establishing features of the visual-motor reaction of young volleyball players with the direction of the periphery of the vision during the visual perception of moving objects and their influence on the accuracy of the attacking blow, taking into account motor asymmetry.

Methods and material. 66 femaile volleyball players (7-16 years old) were examined. Technical preparedness of 22 femaile volleyball players (14-16 years old) were researched. A computer-based visual-response program and an impact test were used.

Results.The dependence of the motor action on the accuracy of the reaction to the object moving is shown. At binocular perception, 7-9-year-old volleyball players are dominated by the processes of excitation both in the general hit and in the reaction to the irritants presented from the left and from the right sides. Volleyball players 13-16 years demonstrated the balance of nerve processes. Inhibition processes prevailed for athletes 10-12 years old. Proximity to balance of nervous processes was observed for 13-16 year olds when perceived with the left eye. The results of the study showed the correlation of the accuracy of the reaction with the accuracy of the attacking blow in the binocular and monocular perception of moving objects.

Originality.Data on sensorimotor reactions in volleyball have been expanded. Taking into account the versatile perception of moving objects.

Conclusions. Sensory prerequisites for the formation of the accuracy of an attack hit of young volleyball players are considered. The accuracy of the attacking blow by the right (dominant) hand depends on the accuracy of the reaction to the object moving from above-below with binocular perception. The connection of the accuracy of the reaction to a moving object from above with the accuracy of the attacking blow to the left area of the volleyball court increases significantly with the perception of the left eye. The accuracy of the reaction to the moving object from the right-left is less significant for the accuracy of the attacking blow by the right (the dominant) hand compared with the reaction to the object moving from above-below.

Keywords. reaction to a moving object, periphery of visual perception, motor accuracy, motor asymmetry, excitation and inhibition of the nervous system. 


\section{Introduction}

The fast movements of volleyball players place high demands on vision [1]. Player performance depends on visual perception [1]. However, visual perception may be limited to rapid physical fatigue [2], different levels of perception and information processing [3, 4], visual asymmetry [1]. But the rapid development of the gaming situation and the need to control a lot of quick and short events in different parts of the sport ground is the most significant limitation [1]. This may affect the subsequent motor reaction [5, 6], especially on the precision of competitive movements [7]. The impact of attacking blow depends not only on the biomechanical characteristics [8], the coordination of movements [9, 10], manifestation of speed-strength abilities [11] at volleyball. But it depends also on the level of sensory-motor reactivity $[3,12]$ to motor action [6].

All components, from the visual search [12, 13] to motor performance [6], are important. The reaction to a moving object characterizes both the balance of nerve processes $[14,15]$ and spatial precision [16]. The characteristics of the reaction to a moving object are determined by age [5], sex [17], qualification [6, 10], level of physical activity [5], spatial parameters [18]. Especially the effect manifests itself in the conditions of fatigue with impaired visual perception [9] and this reduces the speed of fast visual search [12]. It is known that attacking players have an advantage in such conditions [19]. Interdependence of the movement of the athlete's eyes and body during the performance of motor functions of high accuracy is shown [13].

While, the interdependence of eye and body movement, the accuracy of blocking [20] and passing [21] in the context of the accent visual perception, the constant of psychosemantic operations and psycho-sensory functions $[6,11]$, the data of the lateral visual perception taking into account the motor asymmetry in the performance of the attacking blow [22] is important, especially for young volleyball players.

However, the research of the visual-motor reaction of young volleyball players with the direction of the periphery of the vision in the visual perception of moving objects and their impact on the accuracy of the attacking blow, taking into account motor asymmetry (which determined the purpose of our study) was not revealed.

\section{Participants}

66 femaile volleyball players (7-16 years old) were examined. Technical preparedness of 22 femaile volleyball players (14-16 years old) were researched. Their training experience is 4-5 years. Athletes are healthy, without visual impairment, at the time of the research. Volleyball players agreed to participate in the research. Consent to the use of generated data has been confirmed. The study was conducted in accordance with the Helsinki Declaration (adopted in Helsinki, Finland, in 1964 and revised in October 2000 in Edinburgh, Scotland) and approved by the Ethics Committee of the Cherkasy National University.

\section{Instruments}

Test of visual-motor reaction to a moving object

Computer program was used [23]. Test parameters and procedure have been tested in previous studies [18].

Accuracy test for attacking blow

The attacking blow were performed from zones 4 and 2 after transferring from the partner from zone 3 . The participant performed 10 consecutive attacking blow by the dominant hand (sub-dominant hand) from zone 4, first to the right, and then 10 attacking blow to the left side of the opposite half of the volleyball court after being transferred from the partner from zone 3 . 


\section{Statistical analysis method}

Digital material was processed with the aid of traditional methods of mathematical statistics using Excel. Differences were considered significant at a value of $p<0.05$. The statistical relationship between the values was established on the basis of correlation data. The linear correlation relationship was determined for empirical data that was measured on scales of intervals or ratios. Correlation relation was estimated using the correlation coefficient of Pearson $r_{x y}$.

The indicators were taken into account when $r>0.3$ during correlation analysis. The degree of dependence was determined by the intensity of linkages: moderate $-0.3 \geq \mathrm{r}<0.5$; significant $-0.5 \geq r<0.7$. Weak intensity of linkages was $r<0.3$ and was not taken into account.

\section{Results}

At binocular perception, 7-9-year-old volleyball players are dominated by the processes of excitation both in the general hit and in the reaction to the irritants presented from the left and from the right sides. Volleyball players 13-16 years demonstrated the balance of nerve processes (Table 1). Results of the accuracy of the reaction were not the same for volleyball players of various ages.

The higher accuracy of reactions at the exit of objects from the left zone of the screen was detected for young volleyball players 13-16 years, compared with athletes 10-12 years $(p<0.05)$. Groups of volleyball players 7-9 and 13-16 years showed a high accuracy of the reaction at the exit of objects from the right zone of the screen, compared with athletes $10-12$ years $(\mathrm{p}<0.05)$.

Differences in the accuracy of response when leaving objects from the left and right zones were not found for all studied groups of young volleyball players $(p>0.05)$.

Table 1

Comparison of the accuracy of responses to a moving object of young volleyball players of various ages with binocular perception $(\mathrm{cm})$

\begin{tabular}{|l|c|c|c|c|c|c|}
\hline \multirow{2}{*}{ Indicators } & \multicolumn{2}{|c|}{$\begin{array}{c}\text { Volleyball players } \\
7-9 \\
\text { years old } \\
(\mathrm{n}=25)\end{array}$} & \multicolumn{2}{c|}{$\begin{array}{c}\text { Volleyball players } \\
10-12 \text { years old } \\
(\mathrm{n}=20)\end{array}$} & \multicolumn{2}{c|}{$\begin{array}{c}\text { Volleyball players } \\
13-16 \text { years old } \\
(\mathrm{n}=21)\end{array}$} \\
\cline { 2 - 7 } & $\mathrm{Me}$ & $\bar{X} \pm \mathrm{S}$ & $\mathrm{Me}$ & $\bar{X} \pm \mathrm{S}$ & $\mathrm{Me}$ & $\bar{X} \pm \mathrm{S}$ \\
\hline $\begin{array}{l}\text { Deviation from the } \\
\text { central circle (total) }\end{array}$ & -2.56 & $2.78 \pm 0.43$ & 2.43 & $3.02 \pm 0.59$ & 0.16 & $1.44 \pm 0.42 * \#$ \\
\hline $\begin{array}{l}\text { Deviation from the } \\
\text { central circle at the } \\
\text { exit of objects from } \\
\text { the left zone }\end{array}$ & -2.86 & $2.97 \pm 0.45$ & 1.55 & $3.66 \pm 0.62$ & -0.29 & $2.13 \pm 0.53 \#$ \\
\hline $\begin{array}{l}\text { Deviation from the } \\
\text { central circle at the } \\
\text { exit of objects from } \\
\text { the right zone }\end{array}$ & -1.51 & $2.46 \pm 0.42$ & 2.80 & $3.75 \pm 0.63 *$ & 1.13 & $2.41 \pm 0.50 \#$ \\
\hline
\end{tabular}

Note: ${ }^{*} \mathrm{p}<0.05$ - compared with volleyball players 7-9 years $\# \mathrm{p}<0.05$ - compared with volleyball players $10-12$ years.

Inhibition processes prevailed for athletes 10-12 years old; proximity to balance of nervous processes was observed for 13-16 year olds when perceived with the left eye (Table 2 ). The accuracy of the reaction to the moving object was not the same for volleyball players of various ages, except for the data obtained at the exit of objects from the right zone of the screen. Deviations from the central circle with inconvenient perception of objects by the left eye from the right zone were significant for all age categories of volleyball players. High 
accuracy of reaction based on the total number of deviations and deviations when leaving objects from the left zone of the screen recorded for volleyball players $13-16$ years $(p<0.05)$.

Comparison of the accuracy of responses to a moving object

Table 2

of young volleyball players of various ages with monocular perception (left eye) $(\mathrm{cm})$

\begin{tabular}{|l|c|c|c|c|c|c|}
\hline \multirow{2}{*}{ Indicators } & \multicolumn{2}{|c|}{$\begin{array}{c}\text { Volleyball players } \\
7-9 \text { years old } \\
(\mathrm{n}=25)\end{array}$} & \multicolumn{2}{c|}{$\begin{array}{c}\text { Volleyball players } \\
10-12 \text { years old } \\
(\mathrm{n}=20)\end{array}$} & \multicolumn{2}{|c|}{$\begin{array}{c}\text { Volleyball players } \\
13-16 \text { years old } \\
(\mathrm{n}=21)\end{array}$} \\
\cline { 2 - 8 } & $\mathrm{Me}$ & $\bar{X} \pm \mathrm{S}$ & $\mathrm{Me}$ & $\bar{X} \pm \mathrm{S}$ & $\mathrm{Me}$ & $\bar{X} \pm \mathrm{S}$ \\
\hline $\begin{array}{l}\text { Deviation from the } \\
\text { central circle (total) }\end{array}$ & -3.83 & $4.63 \pm 0.97$ & 1.44 & $3.25 \pm 0.69$ & 1.31 & $1.87 \pm 0.53^{* \#}$ \\
\hline $\begin{array}{l}\text { Deviation from the } \\
\text { central circle at the } \\
\text { exit of objects from } \\
\text { the left zone }\end{array}$ & -4.41 & $4.16 \pm 0.94$ & 2.19 & $4.11 \pm 0.61$ & 0.81 & $1.80 \pm 0.41^{* \#}$ \\
\hline $\begin{array}{l}\text { Deviation from the } \\
\text { central circle at the } \\
\text { exit of objects from } \\
\text { the right zone }\end{array}$ & 0.05 & $3.91 \pm 0.88$ & -0.51 & $3.30 \pm 0.72$ & 1.11 & $2.40 \pm 0.70$ \\
\hline
\end{tabular}

Note: ${ }^{*} \mathrm{p}<0.05$ - compared with volleyball players 7-9 years $\# \mathrm{p}<0.05$ - compared with volleyball players $10-12$ years.

Inhibition processes prevailed for athletes 7-9 and 13-16 years old; proximity to balance of nervous processes was observed for 10-12 year olds when perceived with the left eye (Table 3). The accuracy of the response at the exit of objects from the left zone for volleyball players 10-12 and 13-16 years old ( $>>0.05$ ). At the same time, the lowest rates were recorded for athletes 7-9 years. The high accuracy of the reaction at the exit of objects from the right zone was for volleyball players 13-16 years, compared with 10-12-year-olds $(\mathrm{p}<0.05)$. However, the accuracy of the reaction was almost the same for 7-9 and for 13-16-year-olds ( $p>0.05)$.

Table 3

Comparison of the accuracy of responses to a moving object

of young volleyball players of various ages with monocular perception (right eye) $(\mathrm{cm})$

\begin{tabular}{|c|c|c|c|c|c|c|}
\hline \multirow[t]{2}{*}{ Indicators } & \multicolumn{2}{|c|}{$\begin{array}{c}\text { Volleyball players } \\
7-9 \text { years old } \\
(n=25)\end{array}$} & \multicolumn{2}{|c|}{$\begin{array}{c}\text { Volleyball players } \\
10-12 \text { years old } \\
(\mathrm{n}=20)\end{array}$} & \multicolumn{2}{|c|}{$\begin{array}{c}\text { Volleyball players } \\
13-16 \text { years old } \\
(n=21)\end{array}$} \\
\hline & $\mathrm{Me}$ & $\bar{X} \pm \mathrm{S}$ & $\mathrm{Me}$ & $\bar{X} \pm S$ & $\mathrm{Me}$ & $\bar{X} \pm S$ \\
\hline $\begin{array}{l}\text { Deviation from the } \\
\text { central circle (total) }\end{array}$ & 1.82 & $5.21 \pm 0.78$ & 0.78 & $2.70 \pm 0.54 *$ & 1.68 & $2.39 \pm 0.43 *$ \\
\hline $\begin{array}{l}\text { Deviation from the } \\
\text { central circle at the } \\
\text { exit of objects from } \\
\text { the left zone }\end{array}$ & 2.37 & $5.44 \pm 0.85$ & -0.85 & $3.46 \pm 0.71 *$ & 0.42 & $2.71 \pm 0.53 *$ \\
\hline $\begin{array}{l}\text { Deviation from the } \\
\text { central circle at the } \\
\text { exit of objects from } \\
\text { the right zone }\end{array}$ & -0.27 & $3.72 \pm 1.00$ & 2.40 & $4.79 \pm 0.58$ & 2.82 & $3.21 \pm 0.53 \#$ \\
\hline
\end{tabular}


The results of the study indicated a segnificant correlation of moderate intensity of reaction accuracy with the accuracy of the attacking blow in the binocular perception of moving objects (Table 4). The accuracy of the attacking blow to the left part of the volleyball court depends on the accuracy of the visual-motor reaction to the moving object from above-below.

Table 4

Correlation of the accuracy of the attacking blow by the dominant hand and the accuracy of the visual-motor reaction in the binocular perception of moving objects (r)

\begin{tabular}{|l|c|c|c|c|c|c|}
\hline \multirow{2}{*}{$\begin{array}{l}\text { Accuracy of attacking } \\
\text { blow }\end{array}$} & \multicolumn{5}{|c|}{ The accuracy of the sensory-motor reaction to the moving object } \\
\cline { 2 - 7 } & $\begin{array}{c}\text { From } \\
\text { above and } \\
\text { below }\end{array}$ & $\begin{array}{c}\text { From } \\
\text { above }\end{array}$ & $\begin{array}{c}\text { From } \\
\text { below }\end{array}$ & $\begin{array}{c}\text { From } \\
\text { left- } \\
\text { right }\end{array}$ & $\begin{array}{c}\text { From } \\
\text { left }\end{array}$ & $\begin{array}{c}\text { From } \\
\text { right }\end{array}$ \\
\hline $\begin{array}{l}\text { To the left area of the } \\
\text { volleyball court }\end{array}$ & -0.33 & -0.47 & -0.22 & 0.26 & -0.20 & -0.36 \\
\hline $\begin{array}{l}\text { To the right area of the } \\
\text { volleyball court }\end{array}$ & 0.18 & -0.38 & 0.14 & 0.22 & 0.11 & 0.07 \\
\hline
\end{tabular}

The accuracy of the visual-motor reaction to an object moving from above affects the accuracy of the attacking blow to the left and to the right part of the volleyball court. And the accuracy of the visual-motor reaction to an object moving from the right affects the accuracy of the attacking blow to the left part of the volleyball court.

The accuracy of the attacking blow to the left side of the volleyball court with moderate intensity depends on the accuracy of the visual-motor reaction to the moving object from above $(\mathrm{r}=-0.47)$ when perceived with the right eye. Relatively significant connections of moderate degree are established between the accuracy of the attacking blow to the right side of the volleyball court and the visual-motor reaction to the object moving from the below and from the left $(r=-0.33 ; r=-0.37)$ when perceived with the left eye. A moderate degree of influence of the accuracy of the visual-motor reaction on the object moving from the right to the accuracy of the attacking blow to the left part of the volleyball court was discovered $(\mathrm{r}=-0.31)$.

However, the connection of significant intensity is observed between the accuracy of the visual-motor reaction to the object moving from above, and the accuracy of the attacking blow to the left part of the volleyball court when the moving objects are perceived by the left eye $(r=-0.61)$.

The accuracy of the visual-motor reaction to the moving object from above-below has a moderate impact on the accuracy of the attacking blow to the left and to the right part of the volleyball court by a subdominant hand during binocular perception of moving objects (Table 5).

Table 5

Correlation of the accuracy of the attacking blow by the sub-dominant hand and the accuracy of the visual-motor reaction in the binocular perception of moving objects (r)

\begin{tabular}{|l|c|c|c|c|c|c|}
\hline \multirow{2}{*}{$\begin{array}{l}\text { Accuracy of attacking } \\
\text { blow }\end{array}$} & \multicolumn{5}{|c|}{ The accuracy of the sensory-motor reaction to the moving object } \\
\cline { 2 - 7 } & $\begin{array}{c}\text { From } \\
\text { above and } \\
\text { below }\end{array}$ & $\begin{array}{c}\text { From } \\
\text { above }\end{array}$ & $\begin{array}{c}\text { From } \\
\text { below }\end{array}$ & $\begin{array}{c}\text { From } \\
\text { left-right }\end{array}$ & $\begin{array}{c}\text { From } \\
\text { left }\end{array}$ & $\begin{array}{c}\text { From } \\
\text { right }\end{array}$ \\
\hline $\begin{array}{l}\text { To the left area of the } \\
\text { volleyball court }\end{array}$ & -0.39 & -0.26 & -0.43 & -0.36 & -0.35 & -0.02 \\
\hline $\begin{array}{l}\text { To the right area of the } \\
\text { volleyball court }\end{array}$ & -0.30 & -0.41 & -0.27 & 0.04 & 0.03 & 0.05 \\
\hline
\end{tabular}

The accuracy of the visual-motor reaction to an object moving from above affects the accuracy of the attacking blow to the right part of the volleyball court. And the accuracy of 
the visual-motor reaction to an object moving from below affects the accuracy of the attacking blow to the left part of the volleyball court.

The connection of moderate intensity is established between the accuracy of the attacking blow to the left part of the volleyball court and the visual-motor reaction to the object moving from the left-right, as well as the reaction to the object moving from the left.

Significant connections of moderate intensity was established between the reaction to the object moving from above-below and the accuracy of the attacking blow by a subdominant hand as to the left side $(r=-0.48)$ as to the right side of the volleyball court $(r=-0.39)$ when perceived with the left eye. A significant connection of considerable intensity is detected between the accuracy of the visual-motor reaction to the moving object from below and the accuracy of the attacking blow to the right side of the volleyball court $(r=-0.55)$. The connections of moderate intensity between the accuracy of the attacking blow to the left side of the volleyball court and the visual-motor reaction to the object moving from the left-right $(\mathrm{r}=-0.40)$ and from the right side is also revealed $(\mathrm{r}=-0.41)$.

Significant connections was established between the visual-motor reaction to the object moving from above-below and from above and the accuracy of the attacking blow by a sub-dominant hand to the right side of the volleyball court with the monocular (left eye) perception of moving objects $(\mathrm{r}=-0.39 ; \mathrm{r}=-0.30)$. In this case, a significant connection is detected between the accuracy of the visual-motor reaction to the moving object from below and the accuracy of the attacking blow to the right side of the volleyball court $(r=-0.55)$.

\section{Discussion}

An increase in the accuracy of the reaction established from 7 to 16 years. We interpret our data as more developed sensory anticipation for older athletes, although in the studies of Bosenko, Dolgier [2] and Tarovik, Korobeinikov [14], adolescence is characterized by a predominance of arousal processes over inhibition. This is the basis for more accurate motor responses [24]. Our results confirm the data Vinokurenko, Moiseenko [9] on the best possible visual perception of information from the outside. At the same time, such a feature manifests since 13 years. This fact is proved both in Vinokurenko, Moiseenko [9] and in our research. The influence of sensor systems on the accuracy of movements is confirmed by the data of Rovny, Pasko [7]. In this case, the study of the reaction and technical preparedness of young volleyball players taking into account the subdominant hand, in our opinion, makes it possible to establish sensomotor prerequisites for the formation of precision movements during carrying out of basic technical techniques.

Also, the data obtained by us indicate that the technique of the main competitive motions is formed against the background of high accuracy of the reaction to a moving object. The probability of effective improvement is much higher during reaction to an object moving from above-below, compared with the reaction to the object moving from the left-right. In this case, the influence of the accuracy of the sensor-motor reaction on the accuracy of the attacking blow may increase in the conditions of the sensory asymmetry. We have found that the accuracy of the attacking blow by the right (dominant) hand depends on the accuracy of the sensory-motor reaction to the object moving from above for each type of perception (binocular and monocular).

The constant training of the vertical eye movement allows you to focus on objects at different distances and increase the accuracy of the reaction to the ball. This is very characteristic for volleyball [1]. The accuracy of the attacking blow is higher to the left part of the volleyball court with visual information on the right and left eye. This feature is interpreted by the developed perceptive anticipation of the volleyball players [25], which is related to past experience.

\section{Conclusion}

The processes of excitation are characteristic for volleyball players 7-13 years old, which are more pronounced for 7-9-year-old athletes. A significant increase of the accuracy 
of response when presenting stimuli from the left, as well as the perception of stimuli by the left eye occur at the age of 10-13 years. The accuracy of the attacking blow by the left (subdominant) hand depends on the accuracy of the reaction to the object moving from abovebelow for volleyball players 14-16 years old.

The accuracy of the attacking blow by the right (dominant) hand depends on the accuracy of the reaction to the object moving from above-below with binocular perception. The connection of the accuracy of the reaction to a moving object from above with the accuracy of the attacking blow to the left area of the volleyball court increases significantly with the perception of the left eye.

The accuracy of the reaction to the moving object from the right-left is less significant for the accuracy of the attacking blow by the right (the dominant) hand compared with the reaction to the object moving from above-below.

\section{Bibliography (in language original)}

1. Knudson D., Kluka D. The impact of vision and vision training on sport performance. Journal of Physical Education, Recreation and Dance. 1997, № 68(4). P. 17-24. DOI: https://doi.org/10.1080/07303084.1997.10604922.

2. Босенко А., Долгієр Є. Особливості термінової адаптації центральної нервової системи волейболістів. Педагогічні науки: теорія, історія, інноваційні технології. 2018, № 3(77). Р. 27-38. DOI:10.24139/2312-5993/2018.03/027-038.

3. Скайба О., Пшенична Л., Устименко-Косоріч О. Особливості вегетативної регуляції серцевого ритму у спортсменів з різним рівнем сприйняття та обробки зорової інформації. Регуляторні механізми в біосистемах. 2017, 8 (2), C. 239-243. DOI: https://doi.org/10.15421/021737.

4. Стрельникова Є., Горчанюк Ю., Несен О. Зміни показників технічної підготовленості волейболістів 10-11 років під впливом візуального сприйняття параметрів рухів. Слобожанський науковоспортивний вісник. 2018, № 2(64). C. 57-60. DOI:10.15391/snsv.2018-2.013.

5. Хорошуха М. Особливості змін латентних періодів сенсомоторних реакцій у юних спортсменів 1316 років в залежності від спрямованості їх тренувального процесу. Педагогіка, психологія, медикобіологічні проблеми фізичного виховання і спорту. 2012, 08, C. 103-109.

6. Milić V., Nešić G., Trajković N., Radenković O. Differences in the Situational-Motor Skills (Precision) and Effectiveness of Serbian Volleyball Players of the First and Second League. Facta Universitatis, Series: Physical Education and Sport. 2012, № 10(3). P. 267-275.

7. Ровний А., Пасько В. Залежність точності кидків м’яча в кільце у баскетболістів від функціональної стійкості сенсорних систем. Актуальні проблеми юнаџького спорту: тези доп. ХІІ Міжн. наук.практ. конф. (м. Херсон, 26-27 вересня 2017). Херсон, 2017. С. 55.

8. Кальченко К., Паєвський В. Біомеханічна характеристика ігрової діяльності волейболісток. Спортивні ігри. 2015. № 11. С. 59-62. URL: http://www.sportsscience.org/index.php/game/article/view/99/142.

9. Вінокуренко В., Моісеєнко О. Показники координаційних здібностей та функціонального стану аналізаторних систем волейболістів 13-14 років. Збірник наукових праць Харківської державної академії фізичної культури. 2017, № 4. С. 57-60.

10. Stojanović N., Stojanović T., Stojanović D., Herodek K., Jurko D. The influence of coordination abilities on the precision of forearm passing in Volleyball. Defendology. 2014, № 1(35). P. 75-84. DOI: http://dx.doi.org/10.7251/DEFEN1401003S.

11. Vansteenkiste P., Vaeyens R., Zeuwts L., Philippaerts R., Lenoir M. Cue usage in volleyball: a time course comparison of elite, intermediate and novice female players. Biology of Sport. 2014, № 31(4). P. 295-302. DOI: $10.5604 / 20831862.1127288$.

12. Piras A., Lobietti R., Squatrito S. Response Time, Visual Search Strategy, and Anticipatory Skills in Volleyball Players. Journal of Ophthalmology. 2014. DOI: http://dx.doi.org/10.1155/2014/189268.

13. Ripoll H., Papin J-P., Simonet P. Approche de la fonction visuelle en sport. Le travail humain, Presses Universitaires de France. 1983, № 46 (1), 163-173. URL: https://www.jstor.org/stable/40657230?seq=1.

14. Таровик Н., Коробейніков Г. Функціональний стан центральної нервової системи у підлітків 3 різним рівнем рухової активності. Вісник Черкаського університету. Серія: Біологічні науки. 2014, № 36(329). С. 116-123.

15. Макаренко Н., Лизогуб В. Устойчивость двигательной реакции - как один из критериев уравновешенности нервных процессов. Актуальные проблемы транспортной медицины. 2015, № 4 (42-1). C. 93-97. URL: http://dspace.nbuv.gov.ua/bitstream/handle/123456789/136736/12Makarenko.pdf?sequence $=1$

16. Moúoi A., Balint L. Motor behavior and anticipation - A pilot study of junior tennis players. Procedia Social and Behavioral Sciences. 2015, № 187. P. 448-453. DOI: 10.1016/j.sbspro.2015.03.084. 
17. Notarnicola A., Maccagnano G., Pesce V., Tafuri S., Novielli G., Moretti B. Visual- spatial capacity: gender and sport differences in young volleyball and tennis athletes and non-athletes. BMC Research Notes. 2014, 7. P. 57. DOI: 10.1186/1756-0500-7-57.

18. Петренко Ю., Фролова Л. Інформаційні технології у дослідженні нервової системи людини. Науково-методичні основи використання інформаційних технологій в галузі фізичної культури та cnopmy. 2017, № 1. C. 82-85.

19. Günay A., Ceylan H., Çolakoğolu F., Saygın Ö. Comparison of Coinciding Anticipation Timing and Reaction Time Performances of Adolescent Female Volleyball Players in Different Playing Positions. The Sport Journal. 2019. URL: https://thesportjournal.org/article/comparison-of-coinciding-anticipation-timing-and-reaction-timeperformances-of-adolescent-female-volleyball-players-in-different-playing-positions/.

20. Umezaki S., Kida N., Nomura T. Assessment of the Visual Behavior of Volleyball Players While Blocking the Ball: A Study Using a Wearable Camera. International Journal of Sport and Health Science. 2017, № 15. C. 46-54. URL: http://taiiku-gakkai.or.jp/.

21. Sors F., Lath F., Bader A., Santoro I., Galmonte A., Agostini T., Murdgia M. Predicting the length of volleyball serves: The role of early auditory and visual information. PLOS ONE. 2018, № 13(12). URL: https://doi.org/10.1371/journal. pone.0208174.

22. Loffing F., Schorer J., Hagemann N., Baker J. On the advantage of being left-handed in volleyball: further evidence of the specificity of skilled visual perception. Atten Percept Psychophys. 2012, № 74. P. 446-453. DOI 10.3758/s13414-011-0252-1.

23. Петренко Ю., Коваленко С., Фролова Л., Любченко К., Тимофєєв А., Атамась О. Спосіб визначення збудження і гальмування у центральній нервовій системі: пат. 118142 (51) Україна. № 201701041; заявл. 06.02.2017; опубл. 25.07.2017, Бюл. № 14/2017.

24. Ломов Б. Ф., Сурков Е. Н. Антиципация в структуре деятельности. Москва: Наука, 1980. 279 с

25. Шмаргун В. Урівноваженість нервових процесів у дітей підліткового віку 3 різним рівнем психометричного інтелекту. Актуальні проблеми навчання та виховання людей з особливими потребами. Збірник наукових прац̧ь. 2007. № 3(5). С. 171-180.

\section{References}

1. Knudson, D. \& Kluka, D. (1997). The impact of vision and vision training on sport performance. Journal of Physical Education, Recreation and Dance, 68(4), 17-24. DOI: https://doi.org/10.1080/07303084.1997.10604922.

2. Bosenko, A., Dolgier, E. (2018). Features of urgent adaptation of the central nervous system of volleyball players. Pedagogichni nauky: teoriya, istoriya, innovacijni texnologiyi [Pedagogical sciences: theory, history, innovative technologies], 3(77), 27-38. DOI:10.24139/2312-5993/2018.03/027-038. (in Ukr).

3. Skyba, O., Pshenichna, L., \& Ustymenko-Kosorich, O. (2017). Features of autonomic regulation of heart rhythm in athletes with different levels of perception and processing of visual information. Regulyatorni mexanizmy $v$ biosy'stemax [Regulatory mechanisms in biosystems], 8(2), 239-243. DOI: 10.15421/021737. (in Ukr).

4. Strelnikova, E., Gorchanyuk, Y., \& Nesen, O. (2018). Changes in the indicators of technical readiness of volleyball players aged 10-11 under the influence of visual perception of movement parameters. Slobozhans`ky`j naukovo-sporty vny`j visny`k [Slobozhansky scientific and sports bulletin], 2(64), 57-60. DOI:10.15391/snsv.2018-2.013. (in Ukr).

5. Khoroshukha, M. (2012). Features of changes in latent periods of sensorimotor reactions in young athletes 13-16 years, depending on the direction of their training process. Pedagogika, psyxologiya, medy kobiologichni problemy fizy`chnogo vy`xovannya i sportu [Pedagogy, psychology, medical and biological problems of physical education and sports], 8, 103-109. Retrieved from www.sportpedagogy.org.ua/html/journal/2012-08/12kmfttp.pdf. (in Ukr).

6. Milić, V., Nešić, G., Trajković, N. \& Radenković, O. (2012). Differences in the Situational-Motor Skills (Precision) and Effectiveness of Serbian Volleyball Players of the First and Second League. Facta Universitatis, Series: Physical Education and Sport, 10(3), 267-275. http://facta.junis.ni.ac.rs/pe/pe201203/pe201203-10.pdf

7. Rovny, A., Pasko, V. (2017). Dependence of accuracy of throws of a ball in a ring at basketball players on functional stability of sensory systems. Aktual ni problemy`yunacz kogo sportu [Current issues of youth sports]: tezy` dop. XII Mizhn. nauk.-prakt. Konf, Xerson, Xersons`ky j derzhavny` universy`tet, 2017. http://www.kspu.edu/FileDownload.ashx/Zbirka_tez.PDF?id=67807d65-b83b-486c-b396-6a24a6f30df4. (in Ukr).

8. Kalchenko, K., \& Paevsky, V. (2015). Biomechanical characteristics of volleyball players' game activity. Sporty vni igry [Sports games], 11, 59-62. Available from http://www.sportsscience.org/index.php/game/article/view/99/142. (in Ukr).

9. Vinokurenko, V., Moiseenko, O. (2017). Indicators of coordination abilities and functional state of analytical systems of volleyball players aged 13-14. Zbirny`k naukovy`x pracz`Xarkivs`koyi derzhavnoyi akademiyi 
fizy 'chnoyi kul tury ' [Collection of scientific works of the Kharkiv State Academy of Physical Culture], 4, 57-60. https://khdafk.kh.ua/wp-content/uploads/2017/12/\%E2\%84\%964-2017.pdf. (in Ukrainian).

10. Stojanović, N., Stojanović, T., Stojanović, D., Herodek, K. \& Jurko, D. (2014). The influence of coordination abilities on the precision of forearm passing in Volleyball. Defendology, 1(35), 75-84. DOI:10.7251/DEFEN1401003S.

11. Vansteenkiste, P., Vaeyens, R., Zeuwts, L., Philippaerts, R. \& Lenoir, M. (2014). Cue usage in volleyball: a time course comparison of elite, intermediate and novice female players. Biology of Sport, 31(4), $295-302$. DOI: $10.5604 / 20831862.1127288$.

12. Piras, A., Lobietti, R. \& Squatrito, S. (2014). Response Time, Visual Search Strategy, and Anticipatory Skills in Volleyball Players. Journal of Ophthalmology, 4, 189268. DOI: 10,1155 / 2014/189268.

13. Ripoll, H., Papin, J-P. \& Simonet, P. (1983). Approche de la fonction visuelle en sport. Le Travail Humain, Presses Universitaires de France, 46 (1), 163-173. Available from https://www.jstor.org/stable/40657230?seq=1. (in French).

14. Tarovik, N., \& Korobeynikov, G. (2014). Functional state of the central nervous system in adolescents with different levels of motor activity. Visny`k Cherkas 'kogo universy`tetu. Seriya: Biologichni nauky`[Bulletin of Cherkasy University. Series: Biological Sciences], 36(329), 116-123. (in Ukr)

15. Makarenko, N., \& Lizogub, V. (2015). Stability of the motor reaction - as one of the criteria for the balance of nervous processes. Aktual nule problembl transportnoj medy'cy 'nbl [Current problems of transport medicine], 4(42-1), 93-97. (in Ukr).

16. Moúoi, A. \& Balint, L. (2015). Motor behavior and anticipation - A pilot study of junior tennis players. Procedia - Social and Behavioral Sciences, 187, 448-453. DOI: 10.1016/j.sbspro.2015.03.084.

17. Notarnicola, A., Maccagnano, G., Pesce, V., Tafuri, S., Novielli, G. \& Moretti, B. (2014). Visual- spatial capacity: gender and sport differences in young volleyball and tennis athletes and non-athletes. BMC Research Note, 7. DOI: https://doi.org/10.1186/1756-0500-7-57.

18. Petrenko, Y., \& Frolova, L. (2017). Information technologies in the pre-existing nervous system and people. Naukovo-metody`chni osnovy`vy`kory`stannya informacijny`x texnologij v galuzi fizy`chnoyi kul'tury` ta sportu [Scientific and methodological bases of using information technologies in the field of physical culture and sports], 1, 82-85. (in Ukr).

19. Günay, A., Ceylan, H., Çolakoğolu, F. \& Saygın Ö. (2019). Comparison of Coinciding Anticipation Timing and Reaction Time Performances of Adolescent Female Volleyball Players in Different Playing Positions. The Sport Journal, Volume 21. Available from https://thesportjournal.org/article/comparison-of-coinciding-anticipationtiming-and-reaction-time-performances-of-adolescent-female-volleyball-players-in-different-playing-positions/

20. Umezaki, S., Kida, N. \& Nomura, T. (2017). Assessment of the Visual Behavior of Volleyball Players While Blocking the Ball: A Study Using a Wearable Camera. International Journal of Sport and Health Science, 15, 46-54. Available from http://taiiku-gakkai.or.jp/

21. Sors, F., Lath, F., Bader, A., Santoro, I., Galmonte, A., Agostini, T. \& Murdgia M. (2018). Predicting the length of volleyball serves: The role of early auditory and visual information. PLOS ONE, 13(12). DOI: 10.1371/journal. pone.0208174.

22. Loffing, F., Schorer, J., Hagemann, N. \& Baker, J. (2012). On the advantage of being left-handed in volleyball: further evidence of the specificity of skilled visual perception. Atten Percept Psychophys, 74, 446-453. DOI: 10.3758/s13414-011-0252-1.

23. Petrenko, Yu., Kovalenko, S., Frolova, L., Lyubchenko, K., Tymofeev, A., \& Atamas, O. (2017). The method of determining excitation and inhibition in the central nervous system. Patent Ukraine №. 118142 (51). Kyiv: Institute of Intellectual Property. (in Ukr).

24. Lomov, B. F., \& Surkov, E. N. (1980). Anticipation in the structure of activity. Moskva: Nauka (in Rus)

25. Shmargun, V. (2007). The level of importance of nervous processes in children of adulthood with a growing level of psychometric intelligence. Aktual ni problemy` navchannya ta vy xovannya lyudej z osobly vy 'my potrebamy`. Zbirny`k naukovy`x pracz' [Current problems of education and upbringing of people with special needs. Collection of scientific works], 3(5), 171-180. Available from http://ap.uu.edu.ua/article/230. (in Ukr).

Одержано редакцією: $\quad 17.11 .21$

Прийнято до публікації: 13.12 .21 